\title{
Visual-Spatial and Intrapersonal Intelligence in Learning of Rampak Kendang Art for Elementary School Students
}

\author{
Fery Setyaningrum \& Heni Siswantari
}

Universitas Ahmad Dahlan, Jalan Ki Ageng Pemanahan No. 19 Sorosutan Yogyakarta 55164

E-mail: fery.setyaningrum@pgsd.uad.ac.id

\begin{abstract}
The art of rampak kendang in Patimuan Cilacap Regency is an art that has existed for a long time and is hereditary in the people of Cilacap. In learning the art of rampak kendang, two types of plural intelligence exist and have their character in the form of visual-spatial and intrapersonal intelligence. This study aims to describe how visual-spatial and intrapersonal intelligence can form through the learning art of rampak kendang in elementary school students in Patimuan Cilacap. This research method uses descriptive research with a qualitative approach. Methods of data collection using observation, interviews, and document studies to analyze content, this study uses data validity techniques in the form of source triangulation, with data analysis techniques for data reduction, data presentation, and concluding. This study's results in the form of the formation of visual-spatial and intrapersonal intelligence are influenced by internal, external, textual, and contextual factors. Visuals spatial are formed based on understanding art through the senses, primarily through the eyes in the form of colour and space, then transforming the learning the art of rampak kendang captured by the eye into another type of recording and becoming a musical work that appears. In contrast, intrapersonal intelligence is formed with the ability to understand oneself and act based on understanding, which includes strengths and limitations of self, moods, intentions, motivations, temperament and desires, self-discipline, and self-understanding and respect. This study concludes that visual-spatial intelligence is created in the form of creating space by making floor patterns, observing and recording the trainer and then can mimic the movements of kendang, and the use of dancers 'and musicians' face makeup, and costume selection for performances. Intrapersonal intelligence appears based on listening to and playing music among musicians to create strength in oneself, calm the mood, control oneself, and be motivated so that it becomes more disciplined and more self-respecting and the environment.
\end{abstract}

Keywords: visual-spatial intelligence, intrapersonal intelligence, rampak kendang, elementary school students

Kecerdasan Visual Spasial dan Intrapersonal dalam Pembelajaran Seni Rampak Kendang bagi Siswa Sekolah Dasar

\section{ABSTRAK}

Seni rampak kendang di Patimuan Kabupaten Cilacap merupakan kesenian yang sudah lama ada dan turun temurun pada masyarakat Cilacap. Dalam pembelajaran seni rampak kendang ditemukan ada dua jenis kecerdasan jamak yang ada dan memiliki karakternya sendiri berupa kecerdasan visual spasial dan intrapersonal. Penelitian ini bertujuan untuk mendeskripsikan proses kecerdasan visual spasial dan intrapersonal dapat terbentuk melalui pembelajaran seni rampak kendang pada siswa sekolah dasar di Patimuan Cilacap. Metode penelitian ini menggunakan jenis penelitian deskriptif dengan pendekatan kualitatif. Metode pengumpulan data menggunakan observasi, wawancara dan studi dokumen untuk menganalisis konten, penelitian ini menggunakan teknik keabsahan data berupa triangulasi sumber, dengan teknik analisis datanya reduksi data, penyajian data 
IJCAS Volume 7 No. 1, June 2020 | p-ISSN 2339-191X | e-ISSN 2406-9760

serta penarikan kesimpulan. Hasil penelitian ini berupa proses terbentuknya kecerdasan visual spasial dan intrapersonal dipengaruhi oleh faktor internal, eksternal, tekstual dan kontekstual. Visual spasial terbentuk berdasarkan memahami seni melalui pancaindera khususnya melalui mata berupa warna dan ruang, selanjutnya mentransformasikan bentuk dari pembelajaran seni rampak kendang yang ditangkap mata ke dalam bentuk wujud lain berupa rekaman dan menjadi karya musik yang rampak. Sedangkan kecerdasan intrapersonal terbentuk dengan kemampuan memahami diri sendiri dan bertindak berdasarkan pemahaman yang meliputi kekuatan dan keterbatasan diri, suasana hati, maksud, motivasi, temperamen dan keinginan, disiplin diri serta memahami dan menghargai diri. Kesimpulan penelitian ini adalah kecerdasan visual spasial tercipta berupa menciptakan ruang dengan membuat pola lantai, mengamati dan merekam pelatih kemudian bisa menirukan gerakan kendang, dan penggunaan make-up wajah penari dan pemusik, serta pemilihan kostum untuk pertunjukan. Sedangkan kecerdasan intrapersonal muncul ada berdasarkan mendengarkan dan memainkan musik antar anggota pemusik sehingga membuat kekuatan pada diri, menenangkan suasana hati, dapat mengendalikan diri, termotivasi sehingga menjadi lebih disiplin dan lebih menghargai diri serta lingkungan.

Kata Kunci: kecerdasan visual spasial, intrapersonal, rampak kendang, siswa sekolah dasar

\section{INTRODUCTION}

The art Rampak Kendang Patimuan in Cilacap District is an art that has long existed and hereditary in the Cilacap Community. In learning the art of Rampak Kendang, two types of plural intelligence live and have their character in the form of visualspatial and information intrapersonal. According to Masfiroh (Wijaya, 2018), visual-spatial knowledge can create a design or perception of the visual-spatial world appropriately. Children who can make a building or design area, read maps and charts, make two and three-dimensional works, combine colors well, are the characteristics of children who have intelligence visual-spatial. Then the relationship with music seems kendangs. That is what the author wants to convey in this article.

While Lazear states that intrapersonal intelligence is the ability of selfintrospection that opens opportunities to reflect on oneself so that it is aware of all aspects of the self, such as knowledge of one's feelings own, thought processes, self-reflection and a sense of desire that is possessed. The core of intrapersonal intelligence is twofold, namely self-identity and the ability (ability) to recognize the strengths and weaknesses of oneself, according to Lazear (Utami, 2010). In the preobservation and data analysis, I also found intrapersonal intelligence was the writer wanted to describe in more detail how the process was.

Multiple intelligences is a theory invented by Howard Gardner. Gardner by identifying existing intelligence in humans that is close to the world of psychology. Even now, Multiple intelligences are more often used to dissect children's intelligence in various learning processes in the world of education. According to 
(Gardner, 2003) intelligence in multiple intelligences includes "verbal-linguistic intelligence (intelligent words), logical-mathematical intelligence (intelligent numbers), visual-spatial intelligence (intelligent color-images), musical intelligence (intelligent music-songs), kinesthetic intelligence (intelligent movement), interpersonal intelligence (social intelligent), intrapersonal intelligence (intelligent self), naturalist intelligence (intelligent inside), existential intelligence (intelligent nature)". Cognitive psychologist, Gardner also explained that intelligence is knowledge or ability to package a product or use a skill in a way that is assessed by one or more of cultures Gardner's sin (Jansen, 2018) on page 25.

Furthermore (Yaumi, 2016) on page 5 up to 7 explained the importance of integrated based learning multiple intelligence both from PAUD, elementary, junior high to high school levels to produce human resources more top quality. In addition to printing human resources, according to Gardner in (Agustin, 2013) on page 113 conveyed that the essential theory of multiple intelligences to respect the uniqueness of each individual, various variations of learning methods, realizing some models to assess them and almost no way limited to actualize themselves inworld this. According to the view of multiple intelligences (Gardner, 1993) intelligence can be called an ability that has three main components, namely: (1) The ability to solve problems that occur in real daily life, (2) The ability to address new issues faced to be completed, (3) The ability to create something or offer services that will give rise to appreciation in culture ones. For educators, students are individuals who are unique because they have different abilities and intelligence. Based on the reference, its theory is critical to understand the characteristics of each child's information so that it can be used by teachers to adapt to models and methods of learning in the classroom, with teachers understanding the abilities and intelligence of children, it will be easy to include the various knowledge that students need in their age development.

According to Gardner, multiple intelligences have the concept of different characteristics from the characteristics of pre-existing intelligence (Musfiroh, 2011). These characteristics are as follows: (1) All information is different, but all are equal. In this sense, there is no intelligence that is better or more important than other information. (2) All knowledge possessed by humans in levels that are not the same. All info can explore, developed, and developed optimally. (3) There are many indicators of intelligence in each intelligence. With practice, a person can build on the strengths of his knowledge and thin out weaknesses. (4) All these different bits of information will work together to realize the activities that humans do. One event may require more than one intelligence, and one knowledge can use in various fields. (5) All types of information can found in all or all cross-cultures throughout the world and groups age. (6) The natural stages of each intelligence begin with the ability to make archetypes. Musical knowledge, for example, is characterized by 
the ability to distinguish high and low tones. While spatial information starts with the ability to regulate three dimensions. (7) When a person is mature, data to express through a range of professional pursuits and hobbies. Intelligence Logicalmathematical began as the ability to make archetypes in infancy developed into symbolic mastery in childhood, and finally reached the maturity of expression in the form of a profession as a mathematician, accountant, and scientist. (8) There is a possibility that a child is in a "risky" condition so that if they do not receive assistance special, they will experience failure in specific tasks involving such intelligence.

Based on the various characteristics described by Gardner above, it is essential to know and understand the multiple kinds of information that exist, especially in children, so that children can develop the abilities possessed to the maximum. The age of the students taken is in the upper classes. This study aims to describe the process of spatial and intrapersonal visual intelligence through the learning of art Rampak Kendang in elementary school students in Patimuan Cilacap.

\section{MATERIALS AND METHOD}

This research is qualitative research using an ethnographic approach. Researchers conducted intensive research for three months and participated in all community activities, from preparation and training to stage. Data collection methods are observation, interviews, and documentation studies involving community leaders (trainers), community members, and surrounding communities. Literature studies are periodically following the research findings-content analysis to use in dissecting the results of research in the field. To obtain valid data, the researcher triangulated the sources with related parties such as the Village Apparatus, the Chair of Rampak Kendang in the Patimuan, and the players, as well as the rampak kendang dancer to the local educational institution.

\section{RESULTS}

The results of this study are that in the process of the art of rampak kendang, the ability to lift memories, eyesight, and hearing becomes a new memory to create a work of art. Various information obtained is stored into a more sensitive perception or can call important. Furthermore, it continues into a new memory of movements and floor patterns resulting from memory storage into unique works of art. Subsequent results on the multiple intelligence systems find that this system can be the basis of a pilot in the world of education in Indonesia because children can focus 
Fery Setyaningrum \& Heni Siswantari, Visual-Spatial and Intrapersonal Intelligence ...

on developing certain types of intelligence without having to be burdened with being proficient in other information. With the requirement, that child can develop information or abilities possessed well, focus, and in-depth details. It can see from how to play a musical instrument kendang alternately and mutually control themselves When "beating" a kendang between one player with another. Strengthen the ability of each tool held by the player and play the tempo of the music. Each player has a distinct "penabuh" kendang. So by maximizing each musical instrument playing on the kendang player, it is expected to create a musical kendang game that is pleasant to listen to. In addition to visual-spatial and interpersonal intelligence, in addition to fostering the character of mutual respect, love, great solidarity between performers and dancers of the art of rampak kendangs, it can also heal the trauma of some players and the public. It can also be used as music for meditation, dreaming, silence, reflection as a conclusion to solve problems socially.

\section{DISCUSSION}

In the Rampak Kendang Art Patimuan Community, there are visual-spatial intelligence and intrapersonal intelligence that is reflecting after learning and processing the art will to describing after this, based on the results of interviews with Ratnaningsih (dancer leader) Kendang Rampak Community in Patimuan Cilacap as follows.

"Friends of dancers work together to dance the Rampak Kendang dance well, I know very well how they practice and their enthusiasm that I may not forget, I greatly applaud the Rampak Kendang dancers, they observe me giving directions and movements of all dances, then they start to try little by little to dance, even at their home I also hear they continue to practice. It's not easy, you memorize all the movements and patterns of the floor at one time and then combine them all in a dance that seems to require continuity, focus, intention, and high effort" (Ratnaningsih, 2018)

Describe the results of the interview with the dancer leader in Rampak Kendang by the concept put forward by (Baum, 2005) on page 16 that conveys the key to spatial intelligence is to observe and change three-dimensional visuals or information in one mind and needed memory is to to develop the spatial. Suitability understands causal or functional relationships through observation of spatial information use to navigate the space of sensory perception or visual representation of the world and the production of art in the form of visual information or works of art. In the interview results above Ratnaningsih conveyed that the dancers were very enthusiastic in learning to dance, they applied what Ratnaningsih taught by paying close attention to the exercises from the movements to the floor patterns given, then 
memorizing dance after the dance to dance to remember and try again at home, Ratnaningsih also explained that doing the exercise was not easy; it needed high concentration, strong will, and continuous. The dancers' enthusiasm in learning both in paying close attention to trying at home shows that the dancers can capture the visual space of dance moves and implement it in attempting to return home. This is by the concept of visual intelligence expressed by (Wahyuni, 2015) visual-spatial information is the ability of students to capture the world of visual space accurately and make changes to these perceptions. The interview results above were also added to the effects of an interview with one of the dancers in the Community Cilacap Kendang Patimuan Rampak named Dani and described as follows.

"Yes, sir, we learned to dance with enthusiasm, although it is not easy to quickly memorize the dance moves and floor patterns taught by Ms Ratna we continue to practice with enthusiasm" (Dani, 2018).

Dani, one of the Rampak Kendang dancers, also said the same is related to the process of dancing training in the community, the same thing is also clarified again by other concepts, related to the existence of three keys in defining visual-spatial intelligence, namely:

1. Perceiving, namely capturing and understanding something through the five senses.

2. Visual-spatial is related to the ability of the eye, especially color and space.

3. Transforming, namely shifting the eye-catching thing into another form, for example seeing, watching, recording, interpreting in his mind then pouring into a recording of a work, (Yaumi, 2016) on page 15.

Whereas according to (Andriani, 2009) on page 57, intelligence, visualspatial the capacity to recognize and visualize objects or patterns received by the brain. Based on the above understanding of the critical definitions of children in having spatial-visual intelligence, the researcher connects with data in the field using the results of an interview with one of the dancers in the community Rampak Kendang named Indri Apriyani, which is describing as follows:

"Before we practised in our home pay close attention to what Ms Ratna taught, from her movements to making floor patterns for us, besides that I remember and sometimes record using my cellphone so that if I forget I can see the visuals to help me remember, I record with thoughts and memories as well as it is not uncommon to use your cellphone tools" (Indri, 2018).

The results of the interview above accompanied by evidence in the form of photo documentation: 


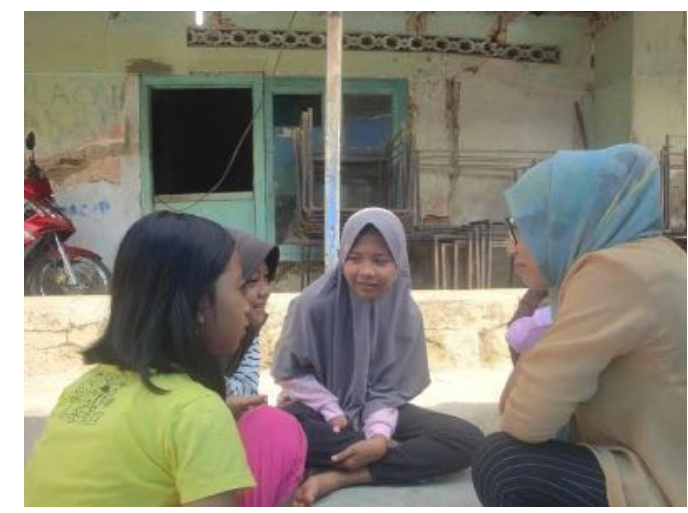

Figure 1. During the interview with the rampak kendang dancer.

Source: Fery Documentation, 2018

Indri enthusiastically conveyed their training process and how they remembered so that they could practice well. The sentences above are consistent with the statement (Rofiah, 2016) from page 71 that intelligence formed through the involvement of cultural values and a person (in the activity) follows a specific pattern of development. In the interview results above the responses memory and the way Indri approached spatial-visual intelligence, it can see from their practice that they do not just rely on movement. Still, they understand and visualize by imagining and recording the exercise's process so that the expected memory process occurs and the achievement of achievement is achieving. A good memory to practice. The following authors attach photo documentation added when the practice process Rampak Kendang dancers as follows:

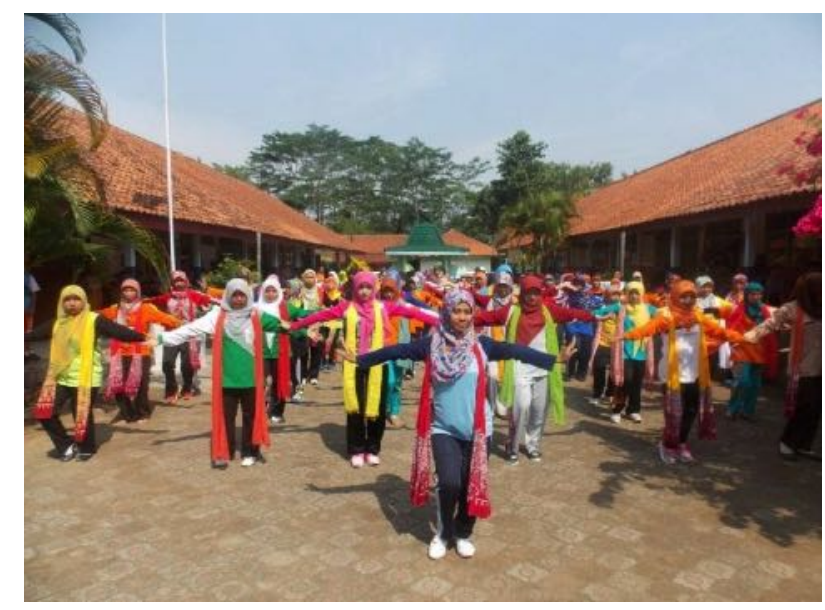

Figure 2. Process the dancers Rampak Kendang exercise Patimuan. Source: Riswanto Documentation, 2018

In addition to the Kendang Rampak dancers, there are also gamelan players who practice before the show. Kendang that will use is preparing in a position best (longitudinal row). Then the players hold kendang each and pay attention to the 
trainer when practising. As evidence, they do practising kendangs by providing photo documentation as follows:

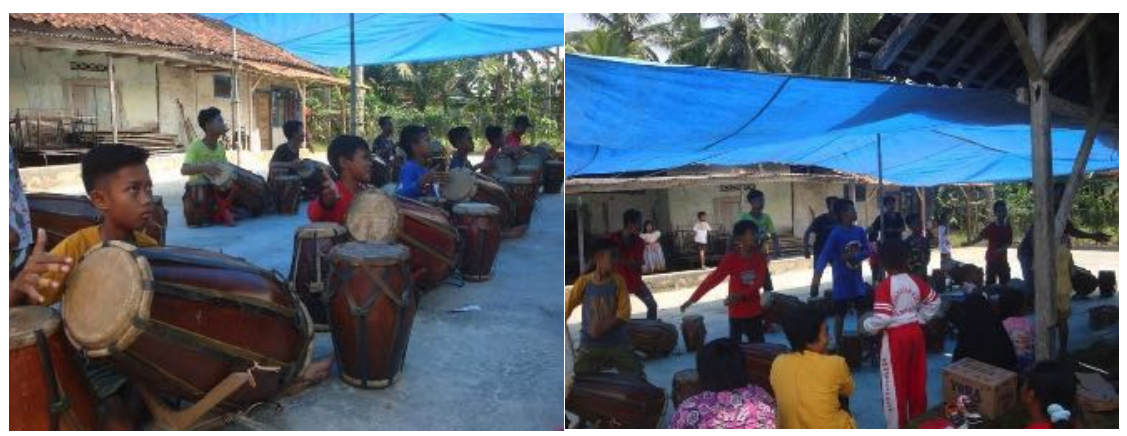

Figure 3. The process of practising gamelan Rampak Kendang Patimuan Source: Riswanto Documentation, 2018

Kendang music game is a group playing music and dance together. The players should have reasonable self-control when playing the instrument. That is for the sake of the realization of harmony in playing the kendang, both in power and tempo. In addition to achieving balance, it can also explore the potential of children playing music through the application of multiple intelligences. Following the statement (Candra, 2015) that implementing systems, numerous bits of intelligence students can boost their deficiencies through their strengths, in the sense of optimizing the characteristics or types of intelligence possessed by students. Every child does not have to have complete information but can maximize the ability of just one or two, for example, in the form of knowledge that the child has provided that develops skills more profoundly and in focus. The following add back evidence of the results of an interview with Riswanto as a kendang player on rampak kendang in Patimuan Cilacap who said that:

If there is someone who is not fast enough to hit the kendang, it should add that it will reduce if there is something too tight. Likewise, if someone has memorized the punch once, they must adjust the other friends. So you cannot win yourself. (Riswanto, 2018)

Riswanto's statement above shows that children's self-ability to hold themselves is very important especially when playing rampak kendang, a player must be able to reflect on their position and role when playing rampak kendang. As photo evidence during an interview with Riswanto as a trainer with rampak kendang, as follows: 


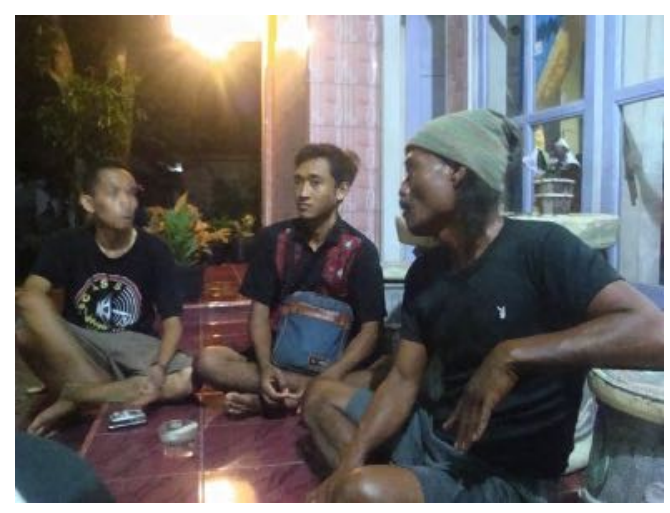

Figure 4. During an interview with Rampak Kendang trainers. Source: Fery Documentation, 2018

When the players can reflect on themselves well, the player can indirectly understand the role of other people in playing rampak kendangs, it is necessary to understand the parts of themselves and others to create harmony. This is following the concept of intrapersonal intelligence put forward by Armstrong in (Kelly, 2015) on page 44 which means that if someone is intelligent in understanding themselves, then he will know himself, know who he is and what can do, and he is aware of the feelings that are Twelve experienced and maybe a better understanding of himself than people others who understand. This is tantamount to the ability to process intrapersonal intelligence by making a separation between oneself both as a subject and object so that communication occurs with oneself well (Hardjana, 2003) on page 47. Following the documentation of the process rampak kendang exercise.

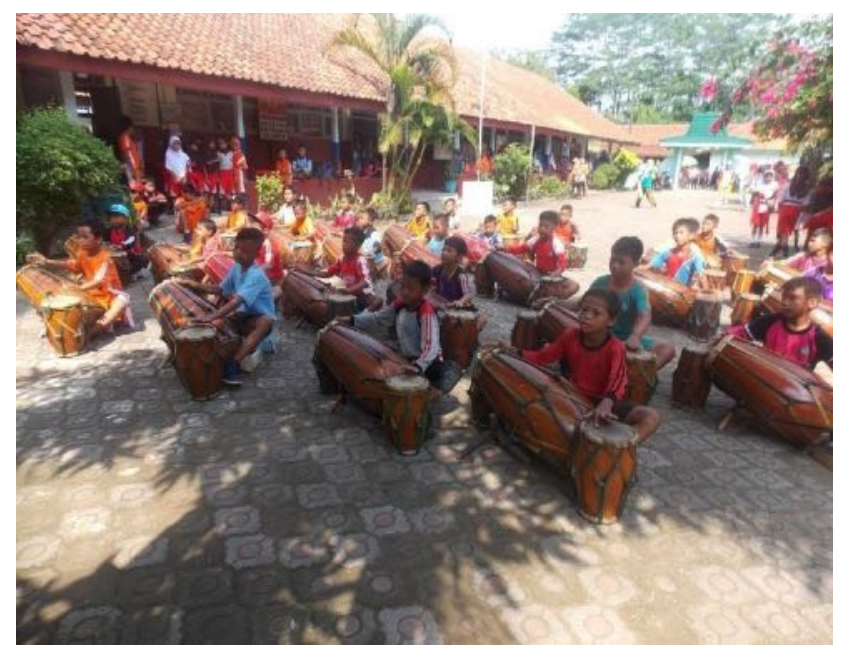

Figure 5. Exercise process music player Rampak Kendang Patimuan in harmonizing the tempo of the music game. Source: Riswanto Documentation, 2018

Intrapersonal intelligence also relates to the environment around the person, friends with social relations. The sentences above are in line with the results of the 
study (Jinky, 2014) on page 20 which states that after the arts, especially the type of group dance that performs rhythmic beatings from the body and singing, they have the effect of ties social, strengthen group solidarity, and prove to be ideal activities even to heal the trauma of something, to enhance the results of research researchers added evidence of photographic photos of the rampak kendang performance when hired for an event in Patimuan Village, on the performance were the performers and dancers seen compact in presenting the show.

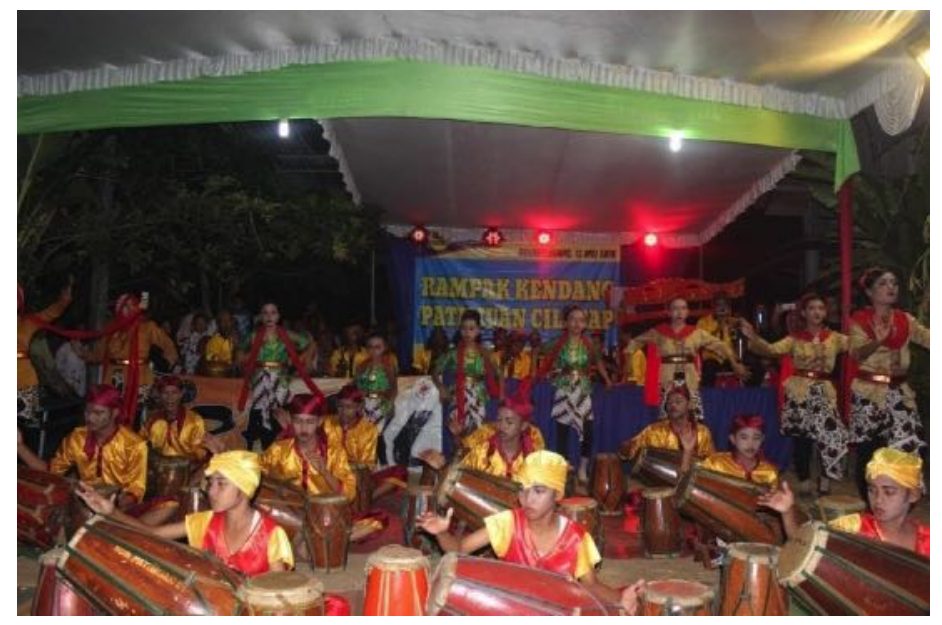

Figure 6. Rampak kendang Patimuan show when at a wedding one of Patimuan residents. Source: Eva Documentation, 2018

The above concept is following the results of an interview with one of the rampak kendang players named Rakim or commonly called pigtails by a friend of his community, as follows:

Yes, sure, miss, his name is like you were eating and sleeping together, playing, training together, yes, it must be very close, just like your sister. How can you not be like that, practice together day and night, know the good and the bad, see if you are angry and what are you happy about, and also yes miss although we are like brothers but instead we become more disciplined because we are not comfortable with each other when not on time. (Rakim, 2018)

Based on the above interview results it can be concluded that after playing music and dance together, the players have a feeling and bond emotional more than ever before, have a sense of solidarity and mutual understanding. Some observations from the research also show that some players are traumatized by something such as trauma with the music itself, such as "Jathilan" music, but over time they recover and are not afraid of it. If the players have a change in the form of abilities that are better than before, then they already have intrapersonal skills following Elmubarok's expression (Amelia, 2017) on page 19 that intrapersonal 
intelligence is an ability which involves: thinking, meditating, dreaming, staying silent, proclaiming goals, reflection, reflection, journaling, self-appraisal, time outs, self-initiated projects, writing, introspection. Intrapersonal intelligence that exists in these children will be able to be following the 2013 curriculum. According to (Machali, 2014) on page 39 the attitude that shows intrapersonal intelligence in the curriculum 2013 appears in the formulation of competencies to achieve that is living and practising honest behavior, discipline, responsibility, caring, cooperation, cooperation, tolerance, peace, courtesy, self-confidence, responsiveness, and proactivity which in essence attitudes shown are part of the solution to various problems in the social environment.

\section{CONCLUSION}

Multiple intelligence in the form of visual-spatial and intrapersonal intelligence found or formed in the process of learning art in the Rampak Kendang Patimuan community by analyzing the main characteristics of visual-spatial were taken from the dancers recording from various ways to remember to be a memory to memorize the shape of movements and floor patterns. From the analysis of the main characteristics of intrapersonal intelligence is the emergence of the character of mutual respect, love, great solidarity between performers and dancers in the Patimuan Rampak Kendang Community. Besides, listening to and playing music between members of the musician to create strength in themselves, calm the mood, control themselves, and motivate them to become more disciplined and more selfrespect and the environment.

\section{REFERENCES}

Agustin, M. (2013). Mengenali dan Mengembangkan Potensi Kecerdasan Jamak Anak Sejak Dini sebagai Tonggak Awal Melahirkan Generasi Emas. Jurnal Cakrawala Dini, 4(2), 113-122. https://doi.org/doi:10.1201/9781420042474.ch5 \n10.1201/9781420042474.c h5

Amelia, D. J. (2017). Analisis Pelaksanaan Pembelajaran Tematik Berorientasi Multiple Intelligences di kelas awal SD Muhammadiyah 9 Malang. Jurnal Pendidikan Dasar Nusantara, 3(1), 13-28. Retrieved from http://ojs.unpkediri.ac.id/index.php/pgsd/article/download/807/565/

Andriani, J. R. (2009). Multiply Intellegences: Melatih 8 Kecerdasan Majemuk pada Anak. Yogyakarta: CV. Andi Offset.

Baum, S. and V. J. and S. B. (2005). Multiple Intelligences In The Elementary Classroom. New York: Teachers College Press.

Candra, M. D. (2015). Penerapan Pembelajaran Berbasis Multiple Intelligences 
Pada Siswa Kelas V Di Sd Juara Gondokusuman Yogyakarta. Jurnal Pendidikan Guru Sekolah Dasar (JPSD) Fakultas Ilmu Pendidikan Universitas Ahmad Dahlan, halaman 1-13.

Gardner, H. (1993). Multiple Intelligence: The Theory in Practice A Reader. New York: Basic Books.

Hardjana, A. (2003). Komunikasi Intrapersonal \& Interpersonal. Yogyakarta: Kanisius.

Jansen, E. (2018). Memperkaya Otak: Cara Memaksimalkan Potensi Setiap Pembelajaran. Jakarta: Indeks.

Jinky, J. C. and S. L. K. O. and I. S. B. and M. S. and S. K. M. (2014). Responses to Tsunami and War Trauma Through the Musical Arts in Aceh, 2005-2012. Wacana Seni Journal of Arts Discourse., Jil./Vol.1.

Kelly, E. (2015). Kecerdasan Interpersonal dan Kecerdasan Intrapeersonal dengan Sikap Multikultural pada Mahasiswa Malang. Jurnal Psikologi, III(1), 39-59.

Machali, I. (2014). Dimensi Kecerdasan Majemuk Dalam Kurikulum 2013. INSANIA: Jurnal Pemikiran Alternatif Kependidikan, 19(1), 21-45. https://doi.org/10.24090/insania.v19i1.462

Musfiroh, T. (2011). Materi Pokok Pengembangan Kecerdasan Majemuk. Jakarta: Universitas Terbuka.

Rofiah, N. H. (2016). Menerapkan multiple intelligences dalam pembelajaran di sekolah dasar. Jurnal Dinamika Pendidikan Dasar, 8(1), 69-79. Retrieved from http://jurnalnasional.ump.ac.id/index.php/Dinamika/article/view/937/875

Utami, A. D. (2010). Peningkatan Kecerdasan Intrapersonal dan Kecerdasan Interpersonal Melalui Pembelajaran Project Approach. Universitas Negeri Jakarta, 7(2), 56.

Wahyuni. (2015). Upaya Meningkatkan Kemampuan Visual Spasial Anak melalui Bermain di Sentra Balok pada Kelompok A TK Himawari Semarang. Penelitian dan Pendidikan, Hal. 95-107.

Wijaya, I. K. W. B. (2018). Mengembangkan Kecerdasan Majemuk Siswa Sekolah Dasar (Sd) Melalui Pembelajaran Ipa Untuk Meningkatkan Mutu Lulusan Sekolah Dasar. Jurnal Penjaminan Mutu, 4, 147-154.

Yaumi, M. \& N. I. (2016). Pembelajaran Berbasis kecerdasan jamak (Learning based on multiple intelligences). Jakarta: Prenadamedia grup. 